\title{
The Requirement of Advantage to Creditors in South African Insolvency Law - a Critical Appraisal
}

\author{
Jean Chrysostome Kanamugire \\ Lecturer, Faculty of Law, North-West University \\ Email: jean.kanamugire@nwu.ac.za \\ Alternative email:kajec1@yahoo.co.uk
}

\section{Doi:10.5901/mjss.2013.v4n13p19}

\section{Abstract}

South African Insolvency law provides for voluntary surrender and compulsory sequestration. The Insolvency Act requires the insolvent debtor to satisfy the court that sequestration will be to the advantage of his or her creditors. Many insolvent debtors face a challenge to prove advantage of creditors as they do not have sufficient assets in their estates. For a creditor to succeed in sequestrating the insolvent estate, he or she must obtain both provisional and final sequestration orders. In granting a provisional sequestration order, the court must be of the opinion that prima facie there is reason to believe that it will be to the advantage of creditors of the debtor if his or her estate is sequestrated. Concerning a final sequestration order, the sequestrating creditor must satisfy the court that there is reason to believe that it will be to the advantage of the creditors of the debtor if his or her estate is sequestrated. The court has a duty to carefully scrutinise friendly sequestrations in order to protect the interest of creditors. At least the court must be satisfied that there are assets for the creditors to obtain a not negligible dividend. Even if there are no assets, the court can still grant the sequestration order, as the investigation and interrogation provided under Insolvency Act may reveal some assets. Poor debtors do not obtain sequestration orders as they cannot prove advantage to creditors if their estates are sequestrated. Society should assist individuals who use their talents and create jobs, even if they fail in the process. It is recommended that advantage to creditors should not be a requirement for sequestration.

Keywords: Insolvent debtors; voluntary surrender, compulsory sequestration, friendly sequestration, advantage to creditors.

\section{Introduction}

The primary function of the Insolvency Act ${ }^{1}$ is to regulate the sequestration of the estates of debtors for the advantage of their creditors. ${ }^{2}$ Sequestration of the insolvent estate may be achieved by voluntary surrender ${ }^{3}$ or compulsory sequestration. ${ }^{4}$ Both require the applicant to prove advantage to creditors. The advantage to creditors is a consideration of great importance in relation to the question whether or not a debtor's estate should be sequestrated. ${ }^{.}$The whole tenor of the Insolvency Act, as it is directly related to sequestration proceedings, is aimed at obtaining a pecuniary benefit for creditors and it is also for that reason that the court will not allow a petitioning creditor to sequestrate the estate of a respondent for other motives. ${ }^{6}$ In a voluntary surrender, the debtor must satisfy the court that sequestration of his or her estate will be to the advantage of his or her creditors. ${ }^{7}$ This is a great challenge, as many debtors often do not have sufficient assets to prove advantage to creditors.

In a compulsory sequestration, the creditor only needs to prove to the court that there is reason to believe that it

\footnotetext{
1 Insolvency Act 24 of 1936.

2 RG Evans \& ML Hoskins "Friendly sequestrations and the advantage of creditors" (1990) 2 SA Merc LJ 246; M Roestoff \& H Coetzee "Consumer debt relief in South Africa; lesson from America and England; and suggestions for the way forward" (2012) 24 SA Merc LJ 53, 55; RG Evans "Law reform in respect of assets in insolvent estates in South Africa" (2010) 22 SA Merc LJ 465, 483; A Boraine \& C van Heerden "To sequestrate or not to sequestrate in view of the National Credit Act 34 of 2005: a tale of two judgments" (2010) 13PELJ 84, 110.

3 Insolvency Act (note 1 above) ss $3-7$.

${ }^{4}$ Ss $9-12$.

${ }^{5}$ Amod v Khan 19472 SA 432 (N) 438.

${ }^{6}$ BP Southern Africa (Pty) Ltd v Furstenburg 19661 SA 717 (O) 720G-H. See also Marshall Industrials Ltd v Pillay and Another 19564 SA 580 (W); R v Meer and Others 19573 SA 614 (N) 619; Cohen v Mallinick 19571 SA 615 (C) 621.

7 Insolvency Act (note 1 above) s 6 (1).
} 
will be to the advantage of creditors of the debtor if his or her estate is sequestrated. ${ }^{8}$ However, the debtor can find a friendly creditor to sequestrate his or her estate. This often occurs when the debtor realises that he or she does not possess sufficient assets to prove that sequestration will be to the advantage of his or her creditors. Sequestration brings about indirect advantages such as investigation and interrogation ${ }^{9}$ of insolvents or witnesses and other statutory measures that may unearth the insolvent's assets for the benefit of creditors. The administration orders provide debt relief for some debtors by reorganisation of their indebtedness. In addition, the National Credit Act ${ }^{10}$ (NCA) plays a significant impact in insolvency measures by emphasising debt restructuring. However, they do not provide the discharge of the debtors. They encourage debtors to ensure total fulfilment of their financial obligations. The winding up of a company does not entail advantage to creditor as a requirement. Poor debtors cannot access insolvency proceedings as they do not have sufficient assets to prove advantage to creditors. In certain circumstances, the insolvent can be rehabilitated and benefit from fresh start mechanisms.

Other jurisdictions, such as the USA and the UK, provide for a fresh start for the debtors and do not necessarily require advantage to creditors. This research paper will look at the meaning of advantage of creditors, critically analyse advantage of creditors in voluntary surrender, compulsory sequestration, friendly sequestration and indirect advantages of sequestration. It will also examine administration order, advantage to creditors in terms of the NCA or winding up a company, difficulties of poor debtors to access insolvency proceeding, rehabilitation and other jurisdictions such as the USA and the UK. Finally, certain recommendations will be made as to whether or not advantage to creditors should be maintained.

\section{Meaning of Advantage of Creditors}

There is no definition of 'advantage of creditors' in the Insolvency Act and thus, to understand the term, we must study how courts have interpreted it. In Lotzof $v$ Raubenheimer, ${ }^{11}$ Botha JP pointed out that the expression to the advantage of creditors' meant advantage of all the creditors, or at least the general body of creditors. The court often presumes that creditors know best what is in their advantage. ${ }^{12}$ Therefore, the court may be influenced, in its decision to grant sequestration, by the fact that it is desired by the creditors. ${ }^{13}$ However, the discretion of the court remains unfettered in all circumstances.

In Walker $v$ Syfret NO, ${ }^{14}$ De Villiers $\mathrm{CJ}$ emphasised that, on sequestration, the rights of the general body of creditors had to be taken into account. He added that no single creditor could thereafter enter into the transaction, with regard to estate matters, that prejudiced the general body. ${ }^{15}$ As a general rule, 'no creditor should obtain any undue advantage over other creditors'. ${ }^{16}$ Therefore, the term 'advantage of creditors' "means the orderly sharing on a just basis of all the assets (with certain exceptions) of the insolvent estate regardless of the seize of the dividend awarded".17

To determine advantage of creditors, "the court must compare the position of the creditors if there is no sequestration with their position if there is a sequestration." ${ }^{18}$ In Gardee $v$ Dhanmanta Holdings and Others, ${ }^{19}$ Didcott J held that sequestration will only be to the advantage of creditors if it exceeds the likely proceeds of an ordinary execution. In this case, the court dismissed the application for sequestration, as there was no reason to believe that sequestration would be more advantageous to creditors than execution. Therefore, the applicant for sequestration needs to prove

\footnotetext{
${ }^{8} \mathrm{~S} 12(1)(\mathrm{C})$.

${ }^{9} \mathrm{~S} 65$.

10 National Credit Act 34 of 2005.

11 Lotzof v Raubenheimer 19591 SA 90 (O) 94; Stainer v Estate Bukes 1933 OPD 86; Amod v Khan 19471 SA 150 (N); Evans \& Hopkins (note 2 above) 246; Roestoff \& Coetzee (note 2 above) 55; CH Smith 'The recurrent motif of Insolvency Act - advantage of creditors' (1985) 7 MBL 27; E Bertelsmann et al Mars The Insolvency Law in South Africa $9^{\text {th }}$ ed (2008) $74-75$.

12 Ex Parte Gardner 1927 CPD 452; Whittle v Whittle 1933 EDL 331 and Borchers v Khaehne 1933 SWA 105.

13 Bertelsmann (note 11 above) 75.

14 Walker v Syfret NO 1911 AD 141.

15 Ibid 146; Richter v Riverside Estates (Pty) Ltd 1946 OPD 209, 223.

${ }^{16}$ Smith (note 11 above) 27.

17 Ibid, 31.

18 O' Flaherty \& Co v Meiklejohn 1940 NPD 371; Gardee v Dhanmanta Holdings and Others 19781 SA 1066 (N) 1068 - 1970; Stainer v Estate Bukes 1933 OPD 86, 90; Madari v Cassim 19502 SA 35 (D) 38; R Sharrock et al Hockly's Insolvency Law 8th ed (2007) 39, South African Law Commission (SALC) Working paper 29, Project 63, Review of the law of insolvency: prerequisites for and alternatives to sequestration (1989) 112.

${ }^{19}$ Gardee v Dhanmanta Holdings and Others (note 18 above) 1070 A; Mamacos v Davids 19761 SA 19 (C) 20C-D.
} 
advantage to creditors.

\section{Advantage to Creditors in Voluntary Surrender}

The Insolvency Act contains formalities ${ }^{20}$ for an insolvent debtor, or his/her agent, or a person entrusted with the administration of the estate of a deceased insolvent debtor, to petition the court for the acceptance of surrender of his or her estate for the benefit of creditors. ${ }^{21}$ Before applying for a voluntary surrender, the person who intends to present the petition shall cause to be published in the Gazette, and in a newspaper circulating in the district in which the debtor resides, or, if the debtor is a trader, in the district in which his or her principal place of business is situated, a prescribed notice of surrender. ${ }^{22}$ The purpose of the notice in the Gazette or newspaper is to inform creditors of the day on which the matter is to be heard or called.

Furthermore, the petitioner must, within a period of seven days from the day of publication of the said notice in the Gazette, deliver or post a copy of the notice to every one of the creditors of the debtor in question whose address he or she knows or can ascertain. ${ }^{23}$ The creditors know promptly of the insolvent debtor's intention to apply for the surrender of his or her estate and they can oppose such application if they so wish. Any creditor of the debtor can inspect the statement of the debtor's affairs during office hours. ${ }^{24}$ In addition, if the debtor is an employer, he or she must also inform every trade union representing his/her employees, the employees themselves and the South African Revenue Services. ${ }^{25}$

The Insolvency Act has a provision for acceptance by the court of surrender of estate. Section 6 (1) provides that if the court is satisfied that the statutory provisions (section 4) have been complied with, that the estate of the debtor in question is insolvent, that he/she owns realisable property of a sufficient value to defray all costs of the sequestration which will, in terms of this Act, be payable out of the free residue of his/her estate and that it will be to the advantage of the creditors of the debtor if his or her estate is sequestrated, it may accept the surrender of the debtor's estate and make an order sequestrating that estate. ${ }^{26}$ In Ex Parte Pillay, ${ }^{27}$ Holmes J stated that "the machinery of voluntary surrender was primarily designed for the benefit of creditors, and not for the release of harassed debtors".

In Ex Parte Bergh, ${ }^{28}$ Centlivres J pointed out that there are two major requirements in a voluntary surrender, "namely, that there must be sufficient reasonable assets to defray the costs of the sequestration, and that the surrender will be to the advantage of creditors". ${ }^{29}$ Therefore, if there is not sufficient asset to pay all the costs of sequestration out of the realisable property, the court cannot accept the surrender. ${ }^{30}$ The same occurs if the surrender will not be to the advantage of creditors. If there are just sufficient assets to pay the costs of sequestration, prima facie, it will not be to the advantage of creditors. ${ }^{31}$ It is salient consideration whether the creditors will receive a dividend from the insolvent estate.

In Ex Parte Smith, ${ }^{32}$ the applicant applied for the surrender of his estate as insolvent and part of the free residue consisted of cash. Potgieter $\mathrm{J}$ acknowledged that the form of the petition had "to contain a specific allegation that the sequestration will be to the advantage of the creditors of the estate - not merely as hitherto an allegation that the petitioner is desirous of surrendering his estate for the benefit of his creditors". ${ }^{33}$ Furthermore, the allegation should be amplified by its supporting facts, unless the figures speak for themselves. ${ }^{34}$ The court will not grant the application if the petition in itself does not show a benefit to creditors, but there is only a bare allegation that the surrender will be to the advantage of creditors, unsupported by evidence or any facts. ${ }^{35}$ However, the learned judge was satisfied that it

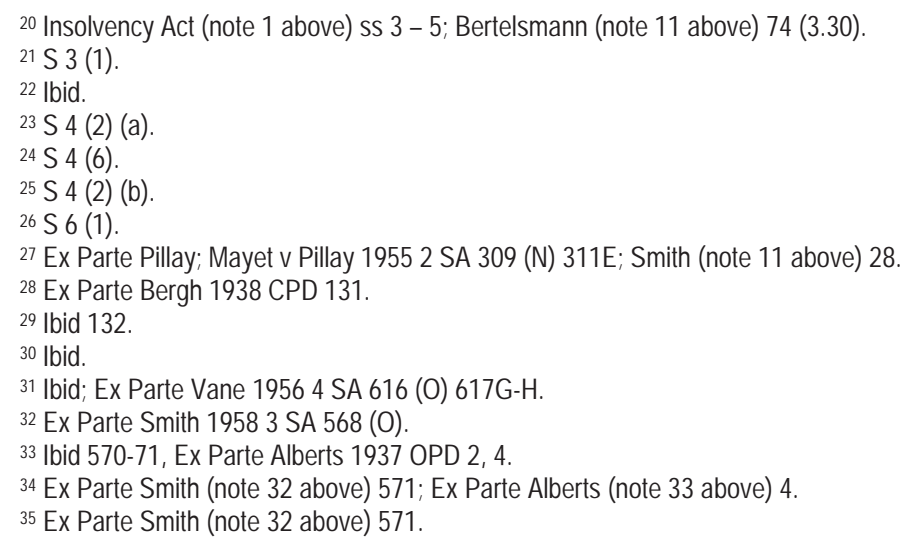


appeared "clearly from the petition that there will be a not negligible dividend and that therefore the petition shows benefit of creditors" ${ }^{36}$ The court accepted the surrender of the estate and placed it under sequestration.

Section 23 (5) provides a possibility for the trustee "to be entitled to any money received or to be received by the insolvent in the course of his profession, occupation and other employment which, in the opinion of the master, are not or will not be necessary for the support of the insolvent and those dependent upon him". ${ }^{37}$ This provision can work for the benefit of creditors. However, the exercise of this right is "very difficult to police and the payment of a portion of the salary, usually tendered to be made in monthly instalments, delays the liquidation of the insolvent estate". ${ }^{38}$ Creditors may wait for a long time before they receive a dividend.

The debtor bears the onus of proof that the surrender will be to the advantage of creditors. In Amod v Khan, ${ }^{39}$ Hathorn JP stated that "a debtor knows all about his own affairs and can easily prove advantage of creditors". This statement is correct for debtors who have sufficient assets to prove advantage to creditors in the application for voluntary surrender of their estates. By contrast, in certain circumstances, some debtors are unable to prove advantage to creditors due to misfortune or otherwise. The debtors, who have inadequate assets to satisfy the court that sequestration will be to the advantage of creditors, cannot successfully surrender their estates. Poor debtors are left to the mercy of their creditors, while those with sufficient assets who can prove advantage to creditors enjoy the benefit of statutory provisions of surrender. Even if the debtors satisfy all the requirements, the court still has discretion to grant or refuse an acceptance of surrender. ${ }^{40} \mathrm{It}$ is submitted that the law needs to be amended to cater for the poorest debtors and alleviate their difficulties.

\section{Advantage of Creditors in Compulsory Sequestration}

A creditor can apply for the sequestration of a debtor's estate. ${ }^{41}$ For a person to succeed in a compulsory sequestration, he or she must obtain a provisional and a final sequestration orders. Section 10 of Insolvency Act deals with provisional sequestration. The court considering the sequestration of the estate of a debtor must be of the opinion that prima facie (a) the petitioning creditor has established against the debtor a liquidated claim of at least R100, or R200 in aggregate for two or more creditors; and (b) the debtor has committed an act of insolvency or is insolvent; and (c) there is reason to believe that it will be to the advantage of creditors if his/her estate is sequestrated. ${ }^{42}$ If these requirements are satisfied, the court has discretion to make an order sequestrating the estate of the debtor provisionally. ${ }^{43}$

If the court sequestrates the estate of a debtor provisionally, it must simultaneously grant a rule nisi, calling upon the debtor, on a day mentioned in the rule, to appear and show cause why his or her estate should not be finally sequestrated. ${ }^{44}$ This provision also confers an opportunity for other creditors to oppose a final sequestration order if they believe that it will not be to the advantage of the debtor's creditors to sequestrate his or her estate.

For a court to exercise its discretion to grant or refuse a final sequestration order, in hearing pursuant to the rule nisi, one of the requirements is that the court must be "satisfied that there is reason to believe that it will be to the advantage of creditors of the debtor if his estate is sequestrated." 45 In essence, the "advantage to creditors" requirement entails that, in order to have access to the formal sequestration proceedings, a debtor's estate should, if realised, yield a dividend to concurrent creditors. ${ }^{46}$ If, at hearing the rule nisi, a court is not so satisfied, it shall dismiss the petition for the

\footnotetext{
${ }^{36}$ Ibid 370H; Trust Wholesalers \& Woollens (Pty) Ltd v Mackan 19542 SA 109 (N) 111.

37 Insolvency Act (note 1 above) s 23 (5); Ex Parte Mckechnie 1938 WLD 45.

${ }^{38}$ Bertelsmann (note 11 above) 75

${ }^{39}$ Amod v Khan 19472 SA 432 (N) 438; Evans \& Haskins (note 2 above) 250.

40 Insolvency Act (note 1 above) s 6 (1).

${ }^{41} \mathrm{~S} 9(1)$.

42 S 10 (1), (a), (b) and (c). See regarding R100 or R200, s 10 (1) read together with s 9 (1); RG Evans "Unfriendly consequences of a friendly sequestration" (2003) 15 SA Merc LJ 437, 444.

43 Insolvency Act (note 1 above) s 10.

${ }^{44} \mathrm{~S} 11$ (1). S 11 (a) also provides how a provisional order of sequestration should or must be communicated to the debtor (e.g. Gazette); if the debtor is an employer, the employees and their trade union must also be informed (s 11 (2A)).

45 Insolvency Act (note 1 above) s 12 (1) (c). See also Bertelsmann (note 11 above) 138 - 141 (5.35 advantage of creditors); M Roestoff \& S Renke "Debt relief for consumers - the interaction between insolvency and consumer protection legislation (part 2)" (2006) 27 Obiter 98, 99.

${ }^{46}$ J Calitz "Developments in the United States' consumer bankruptcy law: a South African perspective" (2007) 28 Obiter 397, 409-410; London Estates (Pty) Ltd v Nair 19573 SA 591 (D), ABSA Bank Ltd v De Klerk and Related Cases 19994 SA 835 (E); Esterhuizen v Swanepoel and sixteen other cases 20044 SA 89 (W) 102 D-G.
} 
sequestration of the estate of the debtor and set aside the order of provisional sequestration, or require further proof of the matters set forth in the petition and postpone the hearing for any reasonable period, but not sine die. ${ }^{47}$ The procedure may allow the petitioning creditor or others to bring evidence to satisfy or challenge the requirement of advantage to creditors.

In Amod v Khan, ${ }^{48}$ Hathorn JP stated that "the creditor has normally little knowledge of the exact position of the debtor, he probably does not know what creditors he has, nor the amounts he owes, nor the estate he possesses." The learned Judge President concluded that "it is difficult for him to provide satisfactory proof that the sequestration of the debtor's estate will be to the advantage of creditors." 49 The petitioning creditor has to ascertain sufficient information about the debtor's estate to prove advantage to creditors if he or she wants to succeed in a compulsory sequestration. In Meskin \& Co v Friedman, Roper J said:

\begin{abstract}
The phrase "reason to believe", used as it is in both these sections (sections 10 and 12 of the Insolvency Act), indicates that it is not necessary, either at the first or at the final hearing, for the creditor to induce in the mind of the court a positive view that sequestration will be to the financial advantage of creditors. At the final hearing, though the court must be "satisfied", it is not to be satisfied that sequestration will be to the advantage of creditors, but only that there is reason to believe that it will be so. ${ }^{50}$
\end{abstract}

The learned judge held that "the facts put before the court must satisfy it that there is a reasonable prospect - not necessarily a likelihood, but a prospect which is not too remote - that some pecuniary benefit will result to the creditors." ${ }^{51} \mathrm{He}$ added that "it is not necessary to prove that the insolvent has any assets. Even if there are none at all, but there are reasons for thinking that, as a result of enquiry under the Act, some assets may be revealed or recovered for the benefit of creditors, that is sufficient." ${ }^{25}$ Reason to believe must relate to the facts giving rise to such belief..$^{53}$ The belief itself must be rational or reasonable, and to come to such a belief the court must be furnished with sufficient facts to support it. ${ }^{54}$ Investigation and interrogation of the insolvent and witnesses may reveal assets that have been disposed of, and therefore prove advantage to creditors.

\title{
4.1 Friendly sequestration
}

A debtor can find a friendly creditor to institute proceedings to sequestrate his or her estate. In Estate Logie $v$ Priest, ${ }^{55}$ the court said that "it is perfectly legitimate for a creditor to take insolvency proceedings against a debtor for the purpose of obtaining payment of his debt." Smith argues that "an applicant for the sequestration of a debtor's estate may be motivated by considerations of kindness towards the debtor and, indeed, there is nothing wrong with this, provided the sequestration is to the advantage of the general body of creditors." 56 One of the reasons for the existence of "so-called friendly sequestrations is the heavier burden of proof which rests on the applicant for voluntary surrender to establish advantage to creditors." ${ }^{57}$ In fact, he or she has to satisfy the court that sequestration will be to the advantage of creditors

\footnotetext{
47 Insolvency Act (note 1 above) s 12 (2).

48 Amod v Khan 19472 SA 432 (N) 438.

$49 \mathrm{lbid}$. According to attorney MW Lynn (1988 De Rebus 171), it is difficult to decide whether sequestration is to the advantage of creditors. Concurrent creditors frequently either receive no dividend or have to pay a contribution. See SALC (note 18 above) 114.

50 Meskin \& Co v Friedman 19482 SA 555 (W) 558, Epstein v Epstein 19874 SA 606 (C) 609.

51 Meskin \& Co v Friedman (not 50 above) 558, Epstein v Epstein (note 50 above) 609; London Estate (Pty) Ltd v Nair 19573 SA 591

(D) 592G, 593 C; Gardee v Dhanmanta Holdings and Others 19781 SA 1066 (N) 1069 G - 1070 A; Evans \& Hoskins (note 2 above) 249.

52 Meskin \& Co v Friedman 19482 SA 555 (W) 559; Pelunky \& Co v Beiles and Others 1905 TS 370; Wilkins v Pieterse 1937 CPD 165, 170; Estate Salzann v Van Rooyen 1944 OPD 1; Miller v Janks 1944 TPD 127. L Steyn "Insolvency enquiries and the right against selfincrimination: divergent approaches in South Africa and other jurisdictions" 2005 CILSA 415. For the provisions dealing with insolvent enquiries and interrogation for the purpose of the advantage to creditors, see ss 64, 65 and 66 of the Insolvency Act.

53 London Estates (Pty) Ltd v Nair 19573 SA 591 (N) 592.

${ }^{4}$ Dunlop Tyres (Pty) Ltd v Brewitt 19992 SA 580 (W) 585; Hillhouse v Stott; Freban Investments (Pty) Ltd v Itzkin; Botha v Botha 1990 4 SA 580 (W) 585 C-F.

55 Estate Logie v Priest 1926 AD 312, 319; RG Evans "Friendly sequestrations, the abuse of the process of court, and possible solutions for overburdened debtors" (2001) 13 SA Merc LJ 485; C Smith The Law of Insolvency $3^{\text {rd }}$ ed (1988) 74 - 77.

${ }^{56}$ C Smith "Friendly and not so friendly sequestrations" (1981) 3 MBL 58.

${ }^{57}$ A Loubser "Ensuring advantage to everyone in a modern South African insolvency law" (1997) 9 SA Merc LJ 325, 328.
} 
of the debtor's estate. ${ }^{58}$ This is a heavy onus to discharge.

In friendly sequestration proceedings, "there is a possibility that the interest of creditors may be prejudiced." ${ }^{59}$ The court should scrutinise such applications with particular care. ${ }^{60}$ In Klemrock (Pty) Ltd v De Klerk and Another, ${ }^{61}$ Nicholas $\mathrm{J}$ said that "in a case where the respondent is at arm's length with his creditors, his admissions normally constitute weighty evidence, but where the respondent is working hand-in-glove with the sequestrating creditor, such admissions, at any rate where they are not confirmed by affidavit, do not have much probative value." Friendly sequestration should be scrutinised to protect advantage to creditors.

Friendly sequestrations are frequently used to obtain compulsory sequestration by abusing the court process. ${ }^{62}$ Applicants use sections 8 (g) of the Insolvency Act by stating that they have received a letter from the debtor that he/she is unable to satisfy his/her debts when they fall due. In $R v$ Meer and Others, ${ }^{63}$ Holmes J said that

\begin{abstract}
the court could guard against such abuse in two ways: firstly, by paying more regard to the element of advantage to creditors in the petition, especially in cases which savour of friendly sequestration under section 8 (g); secondly by refusing to grant repeated adjournments of the rule nisi unless satisfied, on affidavit, that such would be to the advantage of creditors. ${ }^{64}$
\end{abstract}

Sometimes the debtor may collude with his or her friendly creditor to achieve sequestration. The present friendly sequestrations which come before the courts in KwaZulu-Natal (and other divisions) are merely a strategy to come to the relief of harassed debtors and are not in the least concerned with the benefit of creditors. ${ }^{65}$ Therefore, in most cases, there is a very grave suspicion of collusion. ${ }^{66}$ Cooperation between debtor and creditor is acceptable as long as it does not turn into collusion. ${ }^{67}$ Sometimes collaboration between the debtor and creditor may amount to collusion. For this reason, the court must carefully scrutinise friendly sequestration in order to protect the interest of creditors ${ }^{68}$

In Hillhouse v Stott; Freban Investments (Pty) Ltd v Itzkin; Botha $v$ Botha, ${ }^{69}$ Levison J considered three applications for friendly sequestration. In each case, it appeared that the value of the respondents' assets was little more than the amount of R5 000 which was considered by practitioners to be the minimum necessary to cover the costs of sequestration and of administration of the insolvent estate. ${ }^{70}$ The court analysed whether the requirement of advantage to creditors had been met. Levison J stated that such requirement was not met merely by showing that the value of the debtor's assets exceeded the minimum of R5 000 . The learned judge refused to set guidelines to assist practitioners in ascertaining an acceptable dividend for creditors, as this would be encroaching on the functions of the legislature. ${ }^{71}$ Every case must be judged on its own facts and the discretion of the court to judge each case on such facts must remain unfettered. ${ }^{72}$ In the circumstances of the three cases, the free residue would yield no dividend, a dividend of 0.6 cents in the rand and a dividend of 1.6 cents in the rand, respectively. ${ }^{73}$ The court held that the interest of the creditors had not

\footnotetext{
58 Insolvency Act (note 1 above) s 6 (1).

59 Klemrock (Pty) Ltd v De Klerk and Another 19733 SA 925 (W) 927.

60 Ibid 927; R v Meer and Others 19573 SA 614 (N) 619; A Smith "Caution without bias - The court's treatment of opposition to a friendly sequestration" (1998) 6 JBL 157, 158; A Smith "Cast a cold eye - Some unfriendly views on friendly sequestrations" (1997) 5 JBL 50, 52.

61 Klemrock (Pty) Ltd v De Klerk and Another (note 59 above) 927.

62 Mthimkhulu v Rampersad \& Another (BOE Bank Ltd, intervening creditor) 20003 All SA 512 (N) 514 g-h; Evans (note 55 above) 489 ; Smith (note 56 above) $60-61$.

${ }^{63} \mathrm{R}$ v Meer and Other 19573 SA $614(\mathrm{~N})$.

64 Ibid 619.

${ }^{65}$ Mthimkhulu v Rampersad \& Another (BOE Bank Ltd, intervening creditor) (note 62 above) 516 b; Evans (note 55 above) 490 . Friendly sequestrations are also abused in other jurisdictions.

${ }^{6} \mathrm{Ibid} 516 \mathrm{~b}$. Collusion consists of an agreement between the sequestration creditor and the debtor to suppress facts or to put false evidence before the court or to manufacture evidence in order to make it appear to the court that one of the parties has a cause of action or a ground of defence which, in fact, he has not. (See Mthimkhulu v Rampersad and Another (BOE Bank Ltd, Intervening creditor) (note 62 above) 516 c; Kuhn v Karp 19484 SA 825 (T) 827; Smith (note 62 above) 61.

${ }^{67}$ Mthimkhulu v Rampersad and Another (BOE Bank Ltd, intervening creditor) (note 62 above) 516 h; Evans (note 55 above) 499 ; Loubser (note 57 above) 327.

${ }^{68}$ Mthimkhulu v Rampersad and Another (BOE Bank Ltd, intervening creditor) (note 62 above) $516 \mathrm{~g}$.

69 Hillhouse v Stott, Freban Investments (Pty) Ltd v Itzkin, Botha v Botha 19904 SA 580 (W).

70 Ibid 582 B.

71 lbid 586 D.

72 lbid $586 \mathrm{E}$.

73 Ibid 586 B-C.
} 
been met and declined to make any order.

In Mthimkhulu $v$ Rampersad and Another, ${ }^{74}$ the court recognized the abuse of the court process in friendly sequestrations. They were being used as a strategy to assist the debtors and delay sales-in-execution and were not concerned with the benefit to creditors. Combrinck J considered it desirable to set out certain practice guidelines as the minimum requirements for the application for friendly sequestrations. ${ }^{75}$ The court listed the following minimum requirements for the application for sequestration of a debtor by a friendly creditor:

'(i) sufficient proof of the applicant's locus standi; (ii) sufficient documentary proof of the debt; (iii) reason should be given for the fact that the applicant had no security for the debt; (iv) a full and complete list of the respondent's assets and acceptable evidence upon which the court could determine their true market value; (v) in case of immovable property, the valuer should prove his or her qualifications to make the valuation and his or her experience; (vi) notice of the application was to be given to the bondholder; (vii) full and acceptable reasons on affidavits to be given for an application for the execution of a provisional order'. ${ }^{76}$

Evans criticized the Mthimkhulu case for "setting 'minimum requirements' for the application for sequestration of a debtor by a friendly creditor." ${ }^{77}$ The learned author remarked that "the court generalized by placing all friendly sequestrations under one umbrella and it also gave preference to a class of secured creditors by demanding that notice be given only to the mortgagee, thereby ignoring the principle of concursus creditorum." ${ }^{78}$ Nevertheless, the case law reveals that a court has a duty to scrutinize the application for friendly sequestration with great care, to ascertain advantage for creditors and to prevent prejudice to them. ${ }^{79}$ The Insolvency Act also has measures to provide indirect advantages to creditors.

\subsection{Indirect advantages of sequestration}

The Insolvency Act provides for the interrogation of insolvent and other witnesses ${ }^{80}$ with the aim of discovering concealed assets that belong to the debtor. In Meskin v Friedman, ${ }^{81}$ Roper J has shown that there need not always be immediate financial benefit in determining the interests of creditors. He states that it is sufficient if it is shown that investigation and inquiry under the relevant provisions of the Insolvency Act may unearth assets, thereby benefiting creditors. ${ }^{82}$

For example, in Dunlop (Pty) Ltd $v$ Brewitt, ${ }^{83}$ the respondent was the general manager and surety of the company but alleged that he had no assets whatsoever. He formed a trust whereby his children were beneficiaries and transferred all his assets to it. He claimed that shares in the company were owned by the trust. The purpose of the creation of the trust was to defraud creditors. It was suggested that a trustee, under certain circumstances where a company and a trust are being used as a vehicle to prejudice creditors, should have the right to pierce the corporate veil. ${ }^{84}$ Levison $\mathrm{J}$ remarked that there were reasonable grounds for coming to the conclusion that, upon a proper investigation by way of enquiry under section 65 of the Insolvency Act, a trustee might be able to unearth assets which might then be attached, sold and the proceeds disposed of for the distribution amongst creditors. ${ }^{85}$ The court granted a final sequestration order.

\footnotetext{
${ }^{74}$ Mthimkhulu v Rampersad and Another (note 62 above) 516; Beinash and Co v Nathan (Standard Bank of South Africa Limited intervening) 19983 SA 540 (W).

75 Mthimkhulu v Rampersad and Another (note 62 above) 517 a.

76 Ibid $517 \mathrm{~b}$ - h; Evans (note 55 above) 500 - 501.

77 Evans (note 55 above) 502.

$78 \mathrm{lbid}$.

${ }^{79}$ A Boraine \& M Roestoff "Fresh start procedures for consumer debtors in South African bankruptcy law" (2002) 11 INSOL International Insolvency Review 1, 6; Epstein v Epstein 19874 SA 606 (C), Graggs v Dedekind 19961 SA 935 (C), Ex Parte Steenkamp 19963 SA 822 (W); Van Eck v Kirkwood 19971 SA 289 (SE); Meyer v Batten 19991 SA 746 (C).

80 Insolvency Act (note 1 above) s 65. Sections 64 and 66 may also be used to investigate the affairs of the insolvent debtors. L Steyn (note 52 above) 416; Bertelsmann (note 11 above) chapter 19 (Interrogations 418 - 431.

81 Meskin v Friedman 19482 SA 555 (W) 559.

82 Ibid; Hillhouse v Stott, Freeban Investments (Pty) Ltd v Itkzin, Botha v Botha 19904 SA 580 (W) 585; Awerbuch, Brown \& Co v Le Grange 1939 OPD 20, 33; Wilkins v Pieterse 1937 CPD 1965, 170; Estate Salzmann v Van Rooyen 1944 OPD 1, Miller v Janks 1944 TPD 127; Smith (note 11 above) 32.

${ }^{83}$ Dunlop (Pty) Ltd v Brewitt 19992 SA 580 (W). See also Nedbank Ltd v Robin Patrick Thorpe Case No 7392/ 2008 delivered on 26 September 2008 (NPD). In this case, the court lifted the corporate veil in a company and a trust.

${ }^{84}$ RG Evans "The abuse of the process of the court in friendly sequestration proceedings in South Africa" (2002) 11 Inter Insol Rev 13, 25.

${ }^{85}$ Dunlop (Pty) Ltd v Brewit (note 83 above ) 583.
} 
The courts often lift the corporate veil when the occasion demands. In Land and Agriculture Bank of South Africa $v$ Parker and Others, ${ }^{86}$ Cameron JA said:

The courtsa will themselves, in appropriate cases, ensure that the trust form is not abused. The courts have the power and the duty to evolve the law of trust by adapting the trust idea to the principle of our law (Brawn $v$ Blann and Botha NNO and Another 19842 SA 850 (A) 859F-G). This power may have to be invoked to ensure that trusts function in accordance with principles of business efficacy, sound commercial accountability and the reasonable expectations of outsiders who deal with them. This could be achieved through methods appropriate to each case. ${ }^{87}$ Where trustees of a family trust, including the founder, act in a breach of the duties imposed by the trust deed, and purport on their sole authority to enter into contracts binding the trust, that may provide evidence that the trust form is a veneer that in justice should be pierced in the interest of creditors. ${ }^{88}$

Dunlop is significant, as it demonstrates how the corporate veil of a trust or a corporation can be pierced in order to protect the interest of creditors. It ensures a proper distribution of an insolvent estate among creditors. Individuals may not hide behind entities and thwart creditors to achieve their interests. Van Heerden and Boraine argue that "there might in certain circumstances be a reasonable prospect that the trustee, by invoking aspects of the machinery of the Insolvency Act, such as the setting aside of impeachable transactions provided in section 26 to 30 after an investigation and inquiry, will unearth or recover assets that will yield a pecuniary benefit to creditors." ${ }^{89}$ However, investigation and interrogation provided under the Insolvency Act do not guarantee that assets will be found. Sometimes, they may not reveal anything that is to the advantage of creditors. The worst scenario arises when creditors are required to contribute ${ }^{90}$ to the cost of the sequestration proceedings.

\section{Administration Orders as a Debt Relief Measure}

A debtor in financial trouble can apply for the administration of his or her estate under court supervision. This procedure is available for a debtor who is unable to pay the amount of any court judgment obtained against him or her, or to meet his/her financial obligations, and has no sufficient assets capable of attachment to satisfy such judgment or obligations. ${ }^{91}$ The debtor can apply to the magistrate's court for an administration order providing for the administration of his/her estate and for the payment of his/her debts in instalments or otherwise. ${ }^{92}$ However, the administration order is only restricted to debtors whose indebtedness does not exceed R50 000.93 The debtor must have an income to enable him or her to make regular payment to the administrator to be distributed to creditors.

The Magistrates' Courts Act provides for a hearing of an application for administration order. Any creditor may attend the hearing and provide proof of his or her debt and object to any debt listed by the debtor in the statement of his/her affairs. ${ }^{94}$ It also provides that the debtor may be interrogated by the court and by any creditor, or by the legal representative of such creditor, with regard to "his assets and liabilities; his present and future income and that of his wife living with him; his standard of living, and the possibility of economising; and any other motion that the court may deem relevant." ${ }^{25}$ The enquiry into the debtor's affairs helps to determine how much he/she can afford to pay weekly or monthly to the administrator.

Boraine points out that "the basic philosophy behind administrative orders is to grant the debtor a statutory

\footnotetext{
${ }^{86}$ Land and Agriculture Bank of South African v Parker and Others 20052 SA 77 (SCA).

87 Ibid para 37.

88 Ibid para 37.3 .

${ }^{89} \mathrm{C}$ Van Heerden \& A Boraine "The interaction between the debt relief measures in National Credit Act 34 of 2005 and aspects of insolvency law" (2009) 12 PELJ 22, 46; Walker v Walker 19982 All SA 382 (W) 387, Lynn \& Main Inc v Naidoo 20061 SA 59 (N) 68 69; Commissioner, SARS v Hawker Air Services (Pty) Ltd v Commissioner, SARS v Hawker Aviation Partnership 20064 SA 292 (SCA) para 29.

90 Insolvency Act (note 1 above) s 106. Creditors contribute to the cost of the sequestration when a free residue is insufficient.

${ }^{91}$ Magistrates' Courts Act 32 of 1944, s 74 (1) (a).

${ }_{92} \mathrm{~S} 74$ (1). For a detailed discussion about administration orders, see A Boraine, C van Heerden \& M Roestoff "A comparison between formal debt administration and debt review - the pros and cons of these measures and suggestions for law reform (part 1)" 2012 De Jure $80,83-93$.

${ }^{93}$ Magistrates' Courts Act (note 91 above) s 74 (1) (b) read with GN R 1441, Government Gazette 19435 of 30 October 1998, with effect from 1 November 1998.

${ }_{94} \mathrm{~S} 74 \mathrm{~B}(\mathrm{a})$.

${ }^{95} \mathrm{~S} 74 \mathrm{~B}(\mathrm{e})$. The Magistrates' Courts Act contains other requirements of the administration orders from s 74A - 74W; see also Roestoff \& Coetzeee (note 2 above) $65-67$.
} 
rescheduling of his or her debts without formal discharge in-so-far as the debt has not been paid in full." ${ }^{66}$ The administration orders automatically lapse as soon as the costs of the administration and the listed creditors have been paid in full. ${ }^{97}$ Therefore the debtors who cannot raise funds to discharge all their financial obligations may stay on the administration for the duration of their lives.

In Cape Town Municipality v Dunne, ${ }^{98}$ Corbett J held that "the word 'debts' in the proviso to section 74 (1) of the Magistrates' Courts Act means debts which are due and payable and does not include obligation to pay money in futuro." This means that the debtor must make an alternative arrangement to satisfy debts that will be due and payable in future. Greig argues that "the success of an administration order is put seriously at risk where the order cannot include reductions of in futuro instalments." ${ }^{\prime 99}$ As the administration order does not bar sequestration, ${ }^{100}$ the debtor's estate may be sequestrated by his or her future creditors.

In Weiner NO v Broekhuysen, ${ }^{101}$ Cameron JA interpreted section 74L (2) of the Magistrates' Courts Act regarding remuneration and expenses of the administrator and concluded that remuneration and expenses were subject to a maximum of 12.5 per cent of the moneys collected. Section $74 \mathrm{~J}$ (1) requires a court granting an administration order to compel an administrator to collect payments and effect distributions to creditors at least once every three months. This rule may be departed from either where there is agreement by the creditors or where the court orders otherwise, in any particular case. Greig102 also points out that an additional burden is imposed on the debtor as he or she has to pay the administrator's fees.

The administration orders experience many challenges and criticisms. As many debtors do not maintain regular payments, in practice, an administration order is in many instances a failure. ${ }^{103}$ In addition, "even if the debtors do maintain regular payments most of the payments go into the pockets of the administrators as 'fees' and little is paid to creditors to reduce their debts." 104 Furthermore, there are no set of minimum requirements that administrators need to comply with and they do not belong to any regulatory governing body that can shape their behaviour. ${ }^{105}$ If the administrator is not a lawyer or an accountant, he or she can do as he/she pleases as he/she does not have to comply with any professional ethics. This may lead to undesirable consequences if some administrators disappear with the payments collected from the debtors. It is submitted that administrators should belong to a professional organisation and comply with its ethical rules. Finally, the administration order is only limited to certain debtors and there is a need for another debt relief mechanism for debtors who do not qualify for sequestration or administration.

\section{Advantage to Creditors in the National Credit Act}

Some of the main purposes of the National Credit Act ${ }^{106}$ are to promote "responsibility in the credit market by encouraging responsible borrowing, avoidance of over-indebtedness and fulfilment of financial obligations by consumers; and discouraging reckless credit granting by credit providers and contractual default by consumers." ${ }^{107}$ It also addresses and prevents over-indebtedness of consumers, and provides mechanisms for resolving over-indebtedness based on the principle of satisfaction by the consumer of all responsible financial obligations. ${ }^{108}$ The NCA provides "for a consistent

\footnotetext{
${ }^{96}$ A Boraine "The reform of administration orders within a new consumer credit framework" in M Kelly-Louw, JP Nehf \& P Rott The Future of Consumer Credit Regulation Creative Approaches to Emerging Problems (2008) 187, 190; M Roestoff \& S Renke "Debt relief for consumers - the interaction between insolvency and consumer protection legislation (Part 2)" (2006) 27 Obiter 98, 99.

${ }^{97}$ Magistrates' Court Act (note 91 above) s 74U.

${ }_{98}$ Cape Municipality v Dunne 19641 SA 741 (C) 746 C; Carletonville Huishoudelike Voorsieners (Edms) Bpk v Van Vuuren en'n Ander 9622 SA 296 (T) 300; M Kelly-Louw "Prevention of over-indebtedness and mechanisms for resolving over-indebtedness of South African consumers" in J Niemi,I Ramsay \& WC Whitford (ed) Consumer Credit, Debt and Bankruptcy Comparative and International Perspectives (2009) 175, 193.

99 MA Greig "Administration orders as shark nets" (2000) 117 SALJ 622, 625.

100 Magistrates' Courts Act (note 91 above) S 74R.

101 Weiner NO v Broekhuysen 20024 All SA 96 (SCA) para 26.

102 Greig (note 99 above) 626.

103 Kelly-Louw (note 98 above) 193; A Boraine "Some thoughts on the reform of administration orders and related issues" 2003 De Jure 217, 218.

104 Kelly-Louw (note 98 above) 193; Boraine, van Heerden \& Roestoff (note 92 above) 90.

105 Kelly-Louw (note 98 above) 193.

106 National Credit Act (note 10 above).

$107 \mathrm{~S} 3$ (c) (i) and (ii).

108 S 3 (g).
} 
and harmonised system of debt restructuring, enforcement and judgment." ${ }^{109} \mathrm{It}$ is beyond the scope of this paper to examine the detailed provisions of the prevention of over-indebtedness and reckless credit.

In Ex Parte Ford, ${ }^{110}$ three applications for voluntary surrender were served in the Western Cape High Court. It appeared that a major portion of each of the applicants' debts arose out of credit agreement, as intended by the NCA. There were strong grounds for suspecting some degree of reckless credit extension. The court held that it could invoke the provision of section 85 of the NCA to declare and relieve over-indebtedness. ${ }^{111}$

The court observed that the fact that the NCA leaves the provisions of voluntary surrender in Insolvency Act (sections $4-6$ ) generally unaffected acknowledges that insolvency can arise in a great variety of circumstances, many of them quite unrelated to over-indebtedness arising from credit agreements, as defined in the NCA. ${ }^{112}$ The court stated that insolvents whose misfortune arises out of credit agreement transactions would be well advised to take into account the policy and objects of the NCA, and also its special remedies, before opting to apply for the surrender of their estates under the Insolvency Act, rather than availing of the provisions under the NCA.113

Binns-Ward AJ held that the NCA provides a wide range of remedial relief which could be tailored to the justice of a particular case. The possibilities extended from disallowing the recovery of debt, if it arose from reckless credit, to staying of the accrual of interest thereof and ranking liability. ${ }^{114}$ On the evidence, there was no indication in any of the three applications that proper consideration had been given, in the context of debt counselling, to anything beyond an administered debt collection. Specifically, the debt counsellors engaged by the applicants did not give any consideration to obtaining declaration of reckless credits in respect of any of the debts, as contemplated in terms of section 86 (7) of the NCA. 115

In the exercise of its discretion, the court took into account: (i) the extent to which the applicant had been able to obtain credit from financial and money lending institutions; (ii) their failure to explain adequately why they have not availed themselves of the current, more sophisticated remedies under the NCA, and (iii) that the demonstrated monetary advantage to creditors was marginal. ${ }^{116}$ Binns-Ward AJ held that it was the duty of the court, in the exercise of its discretion, to have proper regard to giving due effect to public policy reflected in the NCA. ${ }^{117}$ That public policy gave preference to rights of responsible credit grantors over reckless credit grantors and enjoined full satisfaction, as far as it might be possible, by the consumer of all responsible financial obligations. ${ }^{118}$ Due to incomplete disclosed facts, the machinery of the NCA was the more appropriate mechanism to be used. The court refused to grant the application for voluntary surrender. This case demonstrates how courts are concerned with the protection of interests of responsible credit providers.

The NCA provides for debt re-arrangement ${ }^{119}$ for consumer debtors whose indebtedness arises from credit agreements. This provision aims to protect the interest of creditors by ensuring that debtors comply with their obligations. Van Heerden and Boraine argue that "it is shortsighted to take the hard and fast view that full satisfaction of debts, as envisaged by debt restructuring in terms of section 86 (7) (c), will always be the preferable option in terms of advantage to creditors." 120 The advantage of creditors depends on circumstances of each case. For example, in certain circumstances, creditors may be better served by insolvency proceedings that allow them a payment of a substantial portion of debt owing to them more quickly than a debt restructuring that might yield a slightly better payment but which spans over the life of the consumer. ${ }^{121}$ In addition, the consumers may default in their obligations under debt restructuring. If this occurs, it is a factor that the court will consider to determine whether sequestration will be to the advantage of creditors.

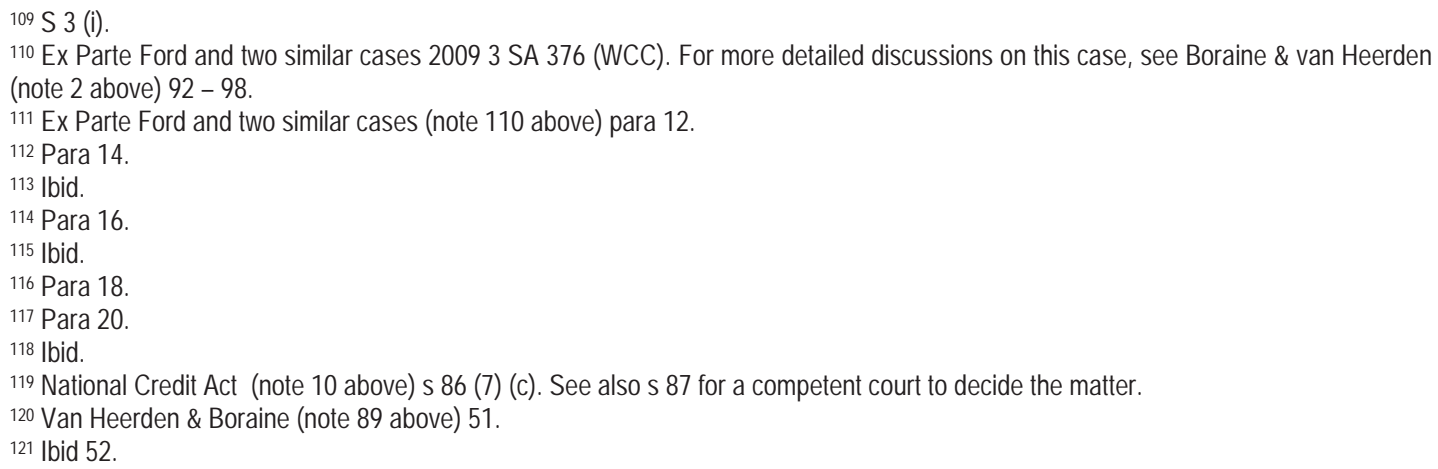




\section{Advantage to Creditors in Winding up an Insolvent Company}

The Companies $\mathrm{Act}^{122}$ does not contain a requirement to the effect that winding up an insolvent company must be to the advantage of creditors. In proceedings for winding up the company, section 447 (1) provides that "the court shall not refuse to make a winding up order on the ground only that the assets of the company have been mortgaged to an amount equal to or in excess of those assets or that the company has no assets."

In Securefin Ltd v KNA Insurance and Investment Brokers (Pty) Ltd, ${ }^{123}$ the applicant applied for the winding up of the respondent company. Mynhardt $\mathrm{J}$ found that the applicant needed not show that it would be to the advantage of creditors of the respondent to grant a winding up order. The fact that a dividend will, or will not, be paid to a creditor who brings an application for the winding up of his debtor ex debito iustitiae is, at the most, a factor to be considered by a court together with all the other relevant factors, in deciding whether or not it will grant a winding up order. ${ }^{124}$ The advantage of creditors is not a requirement in winding up the company. However, there is "no reason why there should be any difference in this regard between cases of winding up and those of sequestration." 125 It is submitted that advantage to creditors should not be a requirement for sequestration, but the court may consider it in the exercise of its discretion. However, the current situation creates challenges for poor debtors to successfully initiate insolvency proceedings.

\section{Inaccessibility of the Insolvency Process for Poor Debtors}

In South Africa, a petitioning creditor must demonstrate that an insolvency filing will be to the advantage of creditors. ${ }^{126}$ The main objective of a sequestration order is to secure the orderly and equitable distribution of a debtor's assets where they are insufficient to meet the claims of all his or her debtors. ${ }^{127}$ In order to obtain sequestration, a person must have assets to distribute and provide advantage to creditors. "At present, a person can be too broke to go bankrupt in South Africa." 128 Therefore, "where the assets in an estate are valueless a sequestration cannot be for the benefit of the creditors." ${ }^{29}$ The court always refuses to grant a sequestration order if it does not provide advantage to creditors.

"If the debtor cannot pay his debts, wholly or in part, and if he himself seeks to escape commercial harassment, it really should be irrelevant whether he has property and, if he has such, what it will contribute towards the meetings of costs and claims." 130 In Kerbel v Chames, Curlewis JP remarked that "the words 'advantage to creditors' have in many cases come to be entirely meaningless." 131 The current insolvency legislation entirely prevents debtors who are too poor to prove advantage to creditors to benefit from the Insolvency Act. As a result, they continue to be under constant harassment by their creditors. This situation needs to be changed, so that all debtors can be accommodated, especially those who have experienced misfortune in their activities.

In the majority of cases it is simply speculation as to whether or not there is reason to believe that sequestration will be advantageous to creditors. ${ }^{132}$ According to a survey conducted in the office of the Master of the Supreme Court, Pretoria, concurrent creditors received dividends in only 28.6 per cent of sequestration cases, while creditors were

122 Companies Act 61 of 1973, ss 337 - 426 (winding up of companies). Companies Act 71 of 2008 has repealed the previous Companies Act 61 of 1973; however, the provisions of the previous Act relating to the winding up of insolvent companies are still in force (see Companies Act 71 of 2008, s 224 and Schedule 5 item 9).

123 Securefin Ltd v KNA Insurance and Investment Brokers (Pty) Ltd 20013 All SA 15 (T).

124 Ibid 27 d-e.

125 SALC (note 18 above) 144

${ }^{126}$ MR Rochelle "Lowering the penalties for failure: using the insolvency law as a tool for spurring economic growth, the American experience, and possible uses for South Africa" 1996 TSAR 315, 318; Insolvency Act (note 1 above) s 10 (c), 12 (1) (c). The same applies for voluntary surrender (s 6 (1)).

127 R Roos "Insolvent municipalities? An analysis of the debt relief mechanisms at the disposal of municipalities and the disappearance of the 'advantage to creditors'" (2007) 22 SAPL 166, 185. Sharrock (note 18 above) 40 (3.1.3: Reason to believe sequestration will be to the advantage of creditors).

${ }^{128}$ Rochelle (note 126 above) 319; Evans (note 2 above) 483; RG Evans "Legislative exclusions or exemptions of property from the insolvent estate" (2011) 14 PELJ 39, 52.

129 Kerbel v Chames 1925 WLD 72, 77.

130 PM Meskin "Advantage to creditors: a misconceived requirement." Unpublished conference paper presented at ABLU (Annual Banking Law Update) hosted by Rand Afrikaans University, Johannesburg, August (1996).

131 Kerbel v Chames (note 129 above) 77; Loubser (note 57 above) 328.

132 Meskin (note 130 above). 
required to pay contributions in 40 per cent of the cases included in the survey. ${ }^{133}$ Evans argues that 'although the Act does not provide for different classes of debtors who are to be treated differently in accordance with differing or changing circumstances, it does in fact differentiate between those rich debtors who are able to prove advantage to creditors, and the "poor debtors" who cannot.'134 It is submitted that the Insolvency Act should be amended to allow all debtors and creditors to obtain sequestration, regardless of whether or not they have proved advantage to creditors. In order to prevent the abuse of the system, debtors who have been dishonest should not be allowed rehabilitation until they have paid all their previous debts. Although insolvency legislation does not intend to benefit debtors, they are entitled to the inherent advantage of sequestration.

\section{Inherent Advantage to Debtors in Insolvency Regimes}

On the sequestration of an estate, all debtors should pay debts that were owed by them to the insolvent before sequestration, to his or her trustee. ${ }^{135}$ The trustee has a duty to pay any dividend that may be available to the creditors of the insolvent. Thus creditors cannot harass the insolvent debtor for their payment. The insolvent has peace of mind in pursuing his or her activities upon sequestration.

The insolvent debtor can exercise a profession, occupation or other employment and be entitled to the remuneration that is necessary for his or her support and those dependent upon him or her. ${ }^{136}$ This also applies for any remuneration or reward for work done or professional service rendered on his/her behalf after sequestration of his/her estate. ${ }^{137}$

An insolvent can apply for rehabilitation ${ }^{138}$ and obtain his or her status before sequestration. There is also a provision for rehabilitation by affluxion of time. The Insolvency Act provides that "any insolvent not rehabilitated by the court, within a period of ten years from the date of sequestration of his or her estate, shall be deemed to be rehabilitated after the expiry of that period, unless a court upon application by an interested person after notice to the insolvent orders otherwise prior to the expiration of the said period of ten years." 139

Rehabilitation has the effect of putting an end to the sequestration; of discharging all debts of the insolvent, which were due, or the cause of which had arisen, before the sequestration, and which did not arise out of any fraud on his/her part; and of relieving the insolvent of every disability resulting from the sequestration. ${ }^{140}$ This is the salient advantage to an insolvent debtor, as he or she obtains a fresh start and regains all the status that he/she enjoyed before sequestration. Unfortunately, this measure is only available to debtors who can prove advantage to creditors and have their estates sequestrated. Poor debtors that are unable to prove advantage to creditors cannot benefit from rehabilitation.

\section{Bankruptcy Provisions in the United States of America (USA)}

The insolvency legislation in the USA has been substantially changed by the Bankruptcy Reform Act ${ }^{141}$ to suit the needs of society. The fundamental goal of the federal bankruptcy law has always been to give debtors a financial fresh start from burdensome debts. ${ }^{142}$ In Local Loan Co $v$ Hunt, the United States Supreme Court held that one of the primary purposes of the Bankruptcy Act was that "it gives to the honest but unfortunate debtor who surrenders for distribution the property which he owns at the time of bankruptcy, a new opportunity in life and a clear field for future effort, unhampered by the pressure and discouragement of pre-existing debts." ${ }^{143}$ Calitz states that "the underlying philosophy of this

${ }^{133}$ A Boraine \& M Roestoff "Developments in American consumer bankruptcy law: lessons for South Africa (Part Two)" (2000) 21 Obiter 241, 263; Boraine (note 96 above) 195; SALC (note 18 above) Schedule 3; Hillhouse v Stott, Freban Investments (Pty) Ltd v Itzkin, Botha v Botha 19904 SA 580 (W) 586 F-G.

134 Evans (note 55 above) 508.

${ }^{135}$ Bertelsmann (note 11 above) 240 (12.10).

136 Insolvency Act (note 1 above) 23 (5).

${ }^{137} \mathrm{~S} 23(9)$.

138 S 124; Loubser (note 57 above) 329.

139 Insolvency Act (note 1 above) s 127 .

${ }^{140} \mathrm{~S} 129$ (1) (a), (b) and (c). The court may impose certain conditions in granting rehabilitation. There are also things that are not affected by rehabilitation in $\mathrm{S} 129$ (3).

${ }^{141}$ Bankruptcy Reform Act 1978. The Act has introduced Chapter 7 (liquidation) and Chapter 13 (individual reorganization).

${ }_{142}$ Calitz (note 46 above) 400.

143 Local Loan Co v Hunt 292 US 234, 244 (1934). 
approach is that the debtor is a victim of unforeseen circumstances and should promptly be allowed back into society without the millstone of perpetual indebtedness." 144

Chapter 7 of the Act is entitled 'liquidations' and contemplates an orderly, court-supervised procedure. It allows the trustee to collect and realize the debtor's assets and distribute them to creditors. ${ }^{145}$ Under Chapter 13 of the Act, an individual may enter into a plan of mostly partial payment to creditors by using disposable income to fund the plan. ${ }^{146}$ The individual must have a regular income to satisfy his or her obligations. Unlike Chapter 7, Chapter 13 does not allow the debtor to receive an immediate discharge of debts and he or she is forced to complete the payments required under the plan before a discharge is received. ${ }^{147}$

The Bankruptcy Abuse Prevention and Consumer Protection Act ${ }^{148}$ (BAPCPA) has amended the Bankruptcy Code. The BAPCPA has introduced new provisions that are mostly creditor-oriented and tries or attempts to tighten abuse and fraud regulations within the bankruptcy system. ${ }^{149} \mathrm{It}$ creates the means-testing and a mandatory education programme. In addition, it retained Chapters 7 and 13, but abolished the debtor's right to choose between them. ${ }^{150}$ Both Chapters 7 and 13 are subject to the means test. For example, under Chapter 13, "instead of debtors proposing their own repayment plans, the new means test determines the debtor's disposable income and requires that they use all of it for five years to repay the creditors." ${ }^{151}$ Thus, in the USA, the debtor can use bankruptcy provisions and obtain a fresh start, regardless of his or her financial wealth.

\section{Debt Relief Provisions in the United Kingdom}

In England and Wales, the County Court Act ${ }^{152}$ governs the administration orders and the payment in terms of the administration order results in an automatic discharge of all debt forming part of the administration order. It amounts to a restructuring of the debts. The total indebtedness of the debtor should not exceed $£ 5000$ and one of the debts must be a judgment debt. The Enterprise Act ${ }^{153}$ brought important changes to insolvency law and introduced new provisions to reduce the stigma attached to bankruptcy. It provides that "a bankrupt is discharged from bankruptcy at the end of the period of one year, beginning with the date on which the bankruptcy commences." ${ }^{154}$

A debtor can apply for a debt relief order. This procedure is appropriate to people who have neither income nor assets (NINA). ${ }^{155}$ To succeed in this application, the debtor should be unable to afford current payment and charges, owe no more than $£ 15000$ in unsecured debts; have assets totalling less than $£ 300$ and have a disposable income of no more than $£ 50$ per month. 156 If these criteria are met, the debt relief order will be granted and the debts will be discharged after 12 months. ${ }^{157}$

The Insolvency Act ${ }^{158}$ offers two formal responses to the insolvency of the natural persons: bankruptcy and individual voluntary arrangement (IVAs). The bankruptcy amounts to a statutory bargain that seeks to balance the interests of debtors and creditors. It has the purpose of staying out of individual enforcement by creditors against

\footnotetext{
144 Calitz (note 46 above) 400.

14511 USC $\S \S 701,704$, Calitz (note 46 above) $401-402$.

${ }^{146}$ Calitz (note 46 above) 402.

147 Ibid.

148 Bankruptcy Abuse Prevention and Consumer Protection Act of 2005.

149 USC § 101 et seq; Calitz (note 46 above) 405.

150 Calitz (note 46 above) 405.

$151 \mathrm{Ibid}$. See also MJ White "Abuse or protection? Consumer bankruptcy reform under BAPCPA" paper presented at the Forum of Economic Policy, Marseille, 12 June 2006, 8 - 9. Available at http://www.economieinternationale.fr/francgraph/communications/pdf/2006/120606/white.pdf (accessed on 4 July 2013).

152 County Court Act of 1984, s 117 (2). Where a debtor has made himself or herself guilty of mala fide conduct in the course of repayment, an interested party can apply to court to refuse a discharge or to grant a discharge, subject to certain conditions (see s 350 (3)).

153 Enterprise Act of 2002.

154 S 256; Roestoff \& Renke (note 45 above) 106.

155 Roestoff \& Renke (note 45 above) 108.

156 Debt Relief Orders. Available at

http://www.abacusfinance.co.uk/debt-relief-order.php (accessed on 4 July 2013)

157 Ibid.

158 Insolvency Act of 1986; A Walters "Individual voluntary arrangements: a 'fresh start' for salaried consumer debtors in England and Wales?" (2009) 18 International Insolvency Review 5, 7.
} 
debtors. ${ }^{159}$ After one year, bankruptcy discharges the debtor's debts and provides a fresh start. ${ }^{160}$ The IVA is a contract between the debtor and his/her creditors that has the effect of discharging the debtor's liabilities. ${ }^{161}$ The debtor makes a formal proposal to his/her creditors to pay a part, or all, of his or her debts. For the IVA to be binding, it must be approved by at least 75 per cent of the creditors by value. 162 IVAs have advantages to creditors, as they offer the prospect of better returns than bankruptcy. ${ }^{163}$ In addition, there may be reputational advantages for institutional creditors in supporting IVAs, rather than resorting to bankruptcy as a collective device. ${ }^{164}$

Insol International 165 has made recommendations to improve insolvency legislation. The first recommendation is that "legislators should enact laws to provide for a fair and equitable, efficient and cost-effective, accessible and transparent settlement and discharge of consumer and small business debts." ${ }^{166}$ This is because society should accept that consumer debtors who cannot repay debts, for reasons beyond their control, are not always solely to blame and that the creditors who consequently received little or no payment are not necessarily the only victims. ${ }^{167}$ Consumer education should be an integral part of a genuine fresh start, as it enables the debtor to function more effectively in society. 168 People should be encouraged to use their talents or skills. Rochelle argues that "society should not reward the cautious man who buries his talent and takes no chances; it most emphatically should do everything in its power to assist the man who creates jobs, the man who strives to turn his one talent into ten - even if he fails in the attempt." ${ }^{169}$ As a policy, society should encourage individuals to use their skills and be creative in their activities, even if they may fail.

\section{Improvements to Advantage of Creditors in the Draft Insolvency Bill}

Clauses 3 and 4 of the Draft Insolvency Bill170 provide, respectively, for the application by a debtor or a creditor for liquidation of a debtor's estate. In all the proceedings for liquidation, the court will grant a provisional liquidation order, as well as a final liquidation order. ${ }^{171}$ However, the court will have discretion to automatically grant a final liquidation order when it deems it just to do so. ${ }^{172}$ Therefore, it will not always be necessary for the court to first grant the provisional liquidation order.

For a final sequestration order, the onus of the debtor to prove advantage to creditors has been amended by the Bill. Irrespective of who applies for liquidation, the onus in respect of advantage to creditors will be the same, if the Draft Insolvency Bill is introduced. ${ }^{173}$ According to the Bill, he or she has to satisfy the court that there is reason to believe that it will be to the advantage of creditors if the debtor's estate is sequestrated. ${ }^{174}$ There is no need for a debtor to resort to friendly sequestration, as the onus is the same for both debtor and creditor. However, a debtor who has no assets at all will not be able to obtain a final liquidation order. The Bill retains 'advantage to creditors' 175 as a requirement.

\section{Conclusion and Recommendations}

Section 6 (1) of the Insolvency Act requires the insolvent debtor to satisfy the court that sequestration will be to the advantage of his or her creditors. This onus is difficult to discharge, as many insolvent debtors do not have sufficient assets to provide for the benefit of creditors. For the creditor to succeed in sequestrating the insolvent estate, he or she

\footnotetext{
159 Insolvency Act (note 158 above) s 285 (3); Walters (note 158 above) 14.

160 Insolvency Act (note 158 above) ss 281 and 282.

161 Walters (note 158 above) 18.

162 Insolvency Act (note 158 above) ss 257, 258 and 260.

163 Walters (note 158 above) 21.

164 Ibid.

165 Insol International "Consumer debt report - report of findings and recommendations", 2001.

166 Ibid 14.

167 lbid.

168 lbid 29.

169 Boraine \& Roestoff (note 133 above) 268; Rochelle (note 126 above) 315.

170 Draft Insolvency Bill 2000.

${ }^{171}$ Clause 7 (provisional liquidation order) and clause 8 (final liquidation order). See also A Boraine \& K van der Linde 'The draft insolvency bill - an explanation (part 1)' 1998 TSAR 621, 630.

172 Draft Insolvency Bill (note 170 above) clause 7 (4).

173 Boraine \& Van der Linde (note 171 above) 632.

174 Draft Insolvency Bill (note 170 above) clause 8 (1) (c).

175 Clauses 7(1) (b) and 8 (1) (c).
} 
must obtain both provisional and final sequestration orders. To procure a provisional sequestration order, the court must be of the opinion that prima facie there is reason to believe that it will be to the advantage of creditors of the debtor if his or her estate is sequestrated. Concerning a final sequestration order, the sequestrating creditor must satisfy the court that there is reason to believe that it will be to the advantage of the creditors of the debtor if his or her estate is sequestrated.

The debtor may find a friendly creditor to sequestrate his or her estate. It is not wrong for the debtor to collaborate or cooperate with his or her friendly sequestrating creditor, but they have to avoid collusion. The court has a duty to carefully scrutinise friendly sequestrations in order to protect the interest of creditors. It must be satisfied that there are assets for the creditors to obtain a not negligible dividend. It is not a requirement to prove that there are assets. Even if there are none, the court can still grant the sequestration order, as the investigation and interrogation, which form part of Insolvency Act, may reveal some assets. Sometimes the corporate veil of entities or trust can be pierced to provide advantage to creditors.

Administration orders assist debtors whose indebtedness is below R50 000 to approach a magistrate's court to surrender their estates to the administrators. This procedure is suitable for debtors who have a regular income and can make monthly payment to the administrator for distribution among creditors. It experiences difficulties, as debtors sometimes default on their regular payments. The administrators do not have to belong to any professional organisation that may shape their behaviour. There is thus a danger that they can misuse the money collected from debtors for their own advantage.

The NCA provides for debt restructuring, debt re-arrangement, avoidance of reckless credit or interest and encourages total satisfaction for all financial obligations by consumers. The court has a duty, in the exercise of its discretion, to have proper regard to giving due effect to public policy reflected in the NCA. This public policy gives preference to rights of responsible credit grantors over reckless credit providers and ensures the full satisfaction, as far as it may be possible, by consumers for all responsible financial obligations.

Poor debtors do not obtain sequestration orders as they cannot prove advantage to creditors if their estates are sequestrated. Although the machinery of the Insolvency Act is not designed to assist debtors, they benefit from inherent advantages of sequestration. As a result, they cannot be harassed by their creditors. They receive rehabilitation and regain their full status prior to the sequestration.

Foreign jurisdictions provide for debt re-organisation, discharge of all debts and ensure that debtors regain their full previous status. In the USA, Chapters 7 and 13 of the Bankruptcy Code provide for liquidation and debt reorganisation, respectively. The BAPCPA has introduced a means test that analyses the debtor's circumstances to ascertain the appropriate measures to take. In the UK, legislation provides for administration orders, debt restructuring and discharge, but advantage to the creditors is not a requirement.

The Draft Insolvency Bill retains the advantage of creditors as a requirement for sequestration. Irrespective of who applies for liquidation, the onus of proof of advantage to the creditors is the same. If the Bill is introduced to law, it will not assist poor debtors who do not have assets to prove advantage to creditors. Society should assist individuals who use their talents and create jobs, even if they fail in the process. It is strongly submitted that advantage to creditors should not be a requirement for sequestration. This will facilitate even poor debtors to successfully apply for sequestration, regardless of their wealth. Measures should be introduced to prevent dishonest debtors from obtaining rehabilitation until they have paid all their previous debts.

\section{References}

\section{Books}

Bertelsmann, E et al Mars The Insolvency Law in South Africa 9th ed (2008)

Sharrock, R et al Hockly's Insolvency Law 8th ed (2007)

Smith, C The Law of Insolvency 3rd ed (1988)

\section{Chapters in books}

Boraine, A 'The reform of administration orders within a new consumer credit framework' in MK Louw, JP Nehf \& P Rott The Future of Consumer Credit Regulation Creative Approaches to Emerging Problems (2008) 187 - 216

Louw, MK 'Prevention of over-indebtedness and mechanisms for resolving over-indebtedness of South African consumers' in J Niemi, I 
Ramsay \& WC Whitford (ed) Consumer Credit, Debt and Bankruptcy Comparative and International Perspectives (2009) 175 197

\section{Journal articles}

Boraine, A \& Van Heerden, C "To sequestrate or not to sequestrate in view of the National Credit Act 34 of 2005: a tale of two judgments" (2010) 13 PELJ 84 - 124

Boraine, A \& Roestoff, M "Developments in American consumer bankruptcy law: lessons for South Africa (Part Two)" (2000) 21 Obiter $241-270$

Boraine, A \& Roestoff, M "Fresh start procedures for consumer debtors in South African bankruptcy law" (2002) 11 INSOL International Insolvency Review 1 - 11

Boraine, A \& Van der Linde, K "The draft insolvency bill - an explanation (part 1)" 1998 TSAR 621 - 646

Boraine, A "Some thoughts on the reform of administration orders and related issues" 2003 De Jure 217 - 251

Boraine, A, Van Heerden, C \& Roestoff, M "A comparison between formal debt administration and debt review - the pros and cons of these measures and suggestions for law reform (part 1)" 2012 De Jure 80 - 103

Calitz, J "Developments in the United States' consumer bankruptcy law: a South African perspective" (2007) 28 Obiter 397 - 417

Evans, RG \& Hoskins, ML "Friendly sequestrations and the advantage of creditors" (1990) 2 SA Merc LJ 246 - 251

Evans, RG "Friendly sequestrations, the abuse of the process of court, and possible solutions for overburdened debtors" (2001) 13 SA Merc LJ 485 - 508

Evans, RG "The abuse of the process of the court in friendly sequestration proceedings in South Africa" (2002) 11 Inter Insol Rev 13 34

Evans, RG "Unfriendly consequences of a friendly sequestration" (2003) 15 SA Merc LJ 437 - 447

Evans, RG "Law reform in respect of assets in insolvent estates in South Africa" (2010) 22 SA Merc LJ 465 - 483

Evans, RG "Legislative exclusions or exemptions of property from the insolvent estate" (2011) 14 PELJ 39 - 56

Greig, MA "Administration orders as shark nets" (2000) 117 SALJ 622 - 626

Loubser, A "Ensuring advantage to everyone in a modern South African insolvency law" (1997) 9 SA Merc LJ 325 - 333

Rochelle, MR "Lowering the penalties for failure: using the insolvency law as a tool for spurring economic growth, the American experience, and possible uses for South Africa" 1996 TSAR 315 - 329

Roestoff, M \& Coetzee, $\mathrm{H}$ "Consumer debt relief in South Africa; lesson from America and England; and suggestions for the way forward" (2012) 24 SA Merc LJ 53 - 76

Roestoff, M \& Renke, S "Debt relief for consumers - the interaction between insolvency and consumer protection legislation (Part 2)" (2006) 27 Obiter 98 - 110

Roos, R "Insolvent municipalities? An analysis of the debt relief mechanisms at the disposal of municipalities and the disappearance of the "advantage to creditors"' (2007) 22 SAPL 166 - 189

Smith, A "Cast a cold eye - Some unfriendly views on friendly sequestrations" (1997) 5 JBL 50 - 52

Smith, A "Caution without bias - The court's treatment of opposition to a friendly sequestration" (1998) 6 JBL 157 - 159

Smith, C "Friendly and not so friendly sequestrations" (1981) 3 MBL 58 - 63

Smith, CH "The recurrent motif of Insolvency Act - advantage of creditors" (1985) 7 MBL 27 - 32

Steyn, L "Insolvency enquiries and the right against self-incrimination: divergent approaches in South Africa and other jurisdictions" 2005 CILSA 415 - 434

Van Heerden, C \& Boraine, A "The interaction between the debt relief measures in National Credit Act 34 of 2005 and aspects of insolvency law" (2009) 12 PELJ 22 - 63

Walters, A "Individual voluntary arrangements: a 'fresh start' for salaried consumer debtors in England and Wales?" (2009) 18 International Insolvency Review 5 - 36

\section{Statutes}

\section{South Africa}

Companies Act 61 of 1973

Insolvency Act 24 of 1936

Magistrates' Courts Act 32 of 1944

National Credit Act 34 of 2005

GN R 1441, Government Gazette 19435 of 30 October 1998

\section{United States of America}

Bankruptcy Reform Act 1978

Bankruptcy Abuse Prevention and Consumer Protection Act of 2005 


\section{United Kingdom}

County Court Act of 1984

Enterprise Act of 2002

Insolvency Act of 1986

\section{Cases}

\section{South Africa}

ABSA Bank Ltd v De Klerk and Related cases 19994 SA 835 (E)

Amod v Khan 19471 SA 150 (N)

Awerbuch, Brown \& Co v Le Grange 1939 OPD 20

Beinash and Co v Nathan (Standard Bank of South Africa Limited intervening) 19983 SA 540 (W)

Borchers v Khachne 1933 SWA 105

BP Southern Africa (Pty) Ltd v Furstenburg 19661 SA 717 (O)

Cape Municipality v Dunne 19641 SA 741 (C)

Carletonville Huishoudelike Voorsieners (Edms) Bpk v Van Vuuren en'n Ander 9622 SA 296 (T)

Cohen v Mallinick 19571 SA 615 (C)

Commissioner, SARS v Hawker Air Services (Pty) Ltd v Commissioner, SARS v Hawker Aviation Partnership 20064 SA 292 (SCA)

Dunlop Tyres (Pty) Ltd v Brewitt 19992 SA 580 (W)

Epstein v Epstein 19874 SA 606 (C)

Estate Logie v Priest 1926 AD 312

Estate Salzmann v Van Rooyen 1944 OPD 1

Esterhuizen v Swanepoel and sixteen other cases 20044 SA 89 (W)

Ex Parte Alberts 1937 OPD 2

Ex Parte Bergh 1938 CPD 131

Ex Parte Ford and two similar cases 20093 SA 376 (WCC)

Ex Parte Gardner 1927 CPD 452

Ex Parte Mckechnie 1938 WLD 45

Ex Parte Pillay; Mayet v Pillay 19552 SA 309 (N)

Ex Parte Smith 19583 SA 568 (O)

Ex Parte Steenkamp 19963 SA 822 (W)

Ex Parte Vane 19564 SA 616 (0)

Gardee v Dhanmanta Holdings and Others 19781 SA 1066 (N)

Graggs v Dedekind 19961 SA 935 (C)

Hillhouse v Stott, Freban Investments (Pty) Ltd v Itzkin, Botha v Botha 19904 SA 580 (W)

Kerbel v Chames 1925 WLD 72

Klemrock (Pty) Ltd v De Klerk and Another 19733 SA 925 (W)

Kuhn v Karp 19484 SA 825 (T)

Land and Agriculture Bank of South African v Parker and Others 20052 SA 77 (SCA)

London Estates (Pty) Ltd v Nair 19573 SA 591 (N)

Lotzof v Raubenheimer 19591 SA 90 (O)

Lynn \& Main Inc v Naidoo 20061 SA 59 (N)

Madari v Cassim 19502 SA 35 (D)

Mamacos v Davids 19761 SA 19 (C)

Marshall Industrials Ltd v Pillay and Another 19564 SA 580 (W)

Meskin \& Co v Friedman 19482 SA 555 (W)

Meyer v Batten 19991 SA 746 (C)

Miller v Janks 1944 TPD 127

Mthimkhulu v Rampersad \& Another (BOE Bank Ltd, intervening creditor) 20003 All SA 512 (N)

Nedbank Ltd v Robin Patrick Thorpe Case No 7392/ 2008 delivered on 26 September 2008 (NPD)

O' Flaherty \& Co v Meiklejohn 1940 NPD 371

Pelunky \& Co v Beiles and Others 1905 TS 370

R v Meer and Other 19573 SA 614 (N)

Richter v Riverside Estates (Pty) Ltd 1946 OPD 209

Securefin Ltd v KNA Insurance and Investment Brokers (Pty) Ltd 20013 All SA 15 (T)

Stainer v Estate Bukes 1933 OPD 86

Trust Wholesalers \& Woollens (Pty) Ltd v Mackan 19542 SA 109 (N) 
Van Eck v Kirkwood 19971 SA 289 (SE)

Walker v Syfret NO 1911 AD 141

Walker v Walker 19982 All SA 382 (W)

Weiner NO v Broekhuysen 20024 All SA 96 (SCA)

Whittle v Whittle 1933 EDL 331

Wilkins v Pieterse 1937 CPD 165

\section{United States of America}

Local Loan Co v Hunt 292 US 234, 244 (1934)

\section{Reports}

Insol International 'Consumer debt report - report of findings and recommendations' (2001)

South African Law Commission (SALC) Working paper 29, Project 63, Review of the law of insolvency: prerequisites for and alternatives to sequestration (1989)

\section{Papers presented}

Meskin, PM "Advantage to creditors: a misconceived requirement." Unpublished conference paper presented at ABLU (Annual Banking Law Update) hosted by Rand Afrikaans University, Johannesburg, August (1996)

White, MJ "Abuse or protection? Consumer bankruptcy Reform under BAPCPA" paper presented at the Forum of Economic Policy, Marseille, 12 June 2006, 1 - 32 http://www.economieinternationale.fr/francgraph/communications/pdf/2006/120606/white.pdf (accessed on 4 July 2013) 